\title{
Apoptosis of colon cancer cells under the effect of geldanamycin derivate
}

\author{
Kosova $\mathrm{F}^{1}$, Kasar $\mathrm{Z}^{2}$, Tuglu $\mathrm{I}^{3}$, Ozdal Kurt $\mathrm{F}^{4}$, Gok $\mathrm{S}^{5}$, Ari $\mathrm{Z}^{6}$, Imren $\mathrm{T}^{1}$ \\ Faculty of Health Science, Celal Bayar University, Manisa, Turkey. fundakosova@gmail.com
}

\begin{abstract}
AIM: The apoptotic effect of geldanamycin derivative may be important for the colorectal cancer therapy. The mechanisms of apoptosis require understanding of the behavior of colon cancer cell line Colo-205 which mimics colon adenocarcinoma. Therefore, the effect of IC50 dose of 17-allylamino-17-demethoxygeldanamycin (17AAG) on the colon cancer cells in vitro was studied for its anti-apoptotic activity.

METHOD: Apoptotic ratio of the Colo-205 cells was determined after 17-AAG application with terminal deoxynucleotidyl transferase dUTP nick end labeling (TUNEL) staining and apoptosis related genes. Apoptosis signal path related key mitochondrial proteins, cytochrome $\mathrm{c}$, bcl-2, caspase 9 and Apaf-1 expression were examined with RT-PCR method.

RESULTS: 17-AAG caused induction of cell death. Apoptotic related genes such as cytochrome-c, Apaf-1 and caspase-9 protein expressions were increased significantly $(p<0.05)$ and anti-apoptotic bcl-2 expression was decreased significantly $(p<0.05)$. Our results indicated that the application of 17-AAG on Colo-205 cells showed anticancer effect by the apoptosis due to alteration of apoptotic genes.

CONCLUSION: The apoptotic effect of $17-A A G$ as an natural product for alternative medicine would be very important for the success and quality of life during the treatment of colon carcinoma with the combination of anticancer drugs (Tab. 1, Fig. 2, Ref. 32). Text in PDF www.elis.sk. KEY WORDS: colon cancer, 17-AAG, apoptosis, RT-PCR, in vitro.
\end{abstract}

\section{Introduction}

Cancer is a disease caused by changes in the critical genes that control cell proliferation, differentiation, survival and apoptosis. Colon cancer stays in third place among the most common types of cancer (1). Many people are diagnosed with colon cancer in the world and most of them die with many complication (2). The prevention of this disease and even at early diagnosis stage is still very difficult with current treatment options. Apoptotic cell death is an important mechanism and target for the anti-cancer treatment $(3,4)$.

The mitochondria-mediated apoptosis occurs with the release of cytochrome-c to cytosol where it is activated. Cytochrome c, cytosolic apoptotic protease activating factor 1 (Apaf-1) and procaspase 9 assemble to form apoptosom. Procaspase 9 turns into this complex to caspase 9 and caspase 9 enables activation of caspase 3 and $7(5,6)$. Thus, cell death occurs $(6)$. One of the most

${ }^{1}$ Faculty of Health Science, Celal Bayar University, Manisa, Turkey, ${ }^{2}$ Department of Chemistry, Celal Bayar University Science and Art Faculty, Manisa, Turkey, ${ }^{3}$ Department of Histology and Embryology, Celal Bayar University Medical Faculty, Manisa, Turkey, ${ }^{4}$ Department of Biology, Celal Bayar University Science and Art Faculty, Manisa, Turkey, ${ }^{5}$ Department of Pharmacology, Celal Bayar University Medical Faculty, Manisa, Turkey, and ${ }^{6}$ Department of Medical Biochemistry, Celal Bayar University Medical Faculty, Manisa, Turkey

Address for correspondence: F. Kosova, MD, Faculty of Health Science, Celal Bayar University, Manisa, Turkey.

Phone: +090.5335573629 important mechanism of apoptosis modulators is $\mathrm{Bcl}-2$ gene. $\mathrm{Bcl}-2$ is the first gene that is determined to protect cells from apoptosis (7). It shows this anti-apoptotic effect by preventing cytochrome $\mathrm{c}$ release and the activation of effector protease. Reduction in the levels of Bcl-2 cells leads to apoptosis and its increase prevents cells from dying (8).

Signaling proteins which have an important task in the initiation and progression of apoptosis are called chaperone. Heat shock proteins as molecular chaperone function in the regulation of cellular homeostasis and cell survival (9). HSP-90, which is a heat shock protein, plays a role in regulating apoptosis by interacting with different proteins at critical control points and prevents apoptosis due to its cell protective property (10). The inhibition of HSP-90 with various agents causes the release of cytochrome c cytosol which plays an important role in the initiation of apoptosis by causing mitochondrial membrane depolarization (11). Geldanamycin, an HSP-90 inhibitor and its derivatives, has apoptosis-inducing effects. Geldanamycin is ansamisin benzoquinone antibiotic which displays anti-carcinogenic effect. 17-AAG is a derivative of geldanamycin. It has been shown that 17-AAG induces apoptosis in colon cancer cell lines by blocking the function of chaperone HSP-90 (12-15). However, the relation of this effect with alteration of related genes is not known very well.

In light of these information, this study aims to investigate the effect of 17-AAG on colon cancer cell line for anti-apoptotic effects due to alterations of related genes. 


\section{Material and methods}

Cell culture and 17-AAG application

Colon cancer cell line Colo-205 was bought from the firm ATCC and was dissolved in accordance with the protocol and then was taken into flasks. Colo-205 cell line was cultured in DMEM F-12, $10 \%$ FCS, $1 \%$ L-glutamine and $1 \%$ penisilin-streptomycine containing cultural medium at $37{ }^{\circ} \mathrm{C}$ and in $5 \% \mathrm{CO}_{2}$ incubator. 17-AAG, a geldanamycin derivative, was prepared in stock solution as $10 \mathrm{mM}$ by dissolving in DMSO solution. Then this prepared stock solution was performed on different cancer cell lines for treatment with $1,3,10,100$ and $500 \mu \mathrm{M}$ doses of 17-AAG to found IC50 which was $8.06 \mathrm{uM}$ (16).

\section{Terminal deoxynucleotidyl transferase dUTP nick end labeling (TUNEL) assay \\ Dead End Colorimetric TUNEL system kit (G7130, Promega,} USA) was used for this technique. After the cells had been incubated with $4 \%$ paraformaldehyde for $10 \mathrm{~min}$, the cells were washed with buffer solution for three times 5 minutes each. After being performed and washed with $4 \%$ paraformaldehyde, the cells that were washed with buffer solution for 5 minutes are incubated for an hour with TdT-enzyme solution at $37{ }^{\circ} \mathrm{C}$. The cells were applied $3 \% \mathrm{H}_{2} \mathrm{O}_{2}$ (TA-015-HP, Lab Vision, Fremont, CA) for five minutes after they are applied $22 \% \mathrm{NaCl}$ and $11 \%$ sodium citrate washed for ten minutes and washed with buffer solution. The cells were washed with buffer solution for 10 minutes at room temperature and were incubated with anti-streptavidin-peroxidase enzyme for 30 minutes. The cells that were washed with buffer solution were dyed with diaminobenzidine (DAB). The cells were washed 3 times for 5 minutes in distilled water. Then they were examined under a microscope by being closed with histomount mounting solution (17).

\section{RNA isolation protocol}

In this study, in the control group and 17-AAG administered group two types of cells were used. Tripur isolation reagent was added to the cells in the flask and the scraped cells were added to the tubes. Then they were centrifuged at $3.000 \mathrm{rpm}$ for $30 \mathrm{sec}$. The cells were taken to the special eppendorf tubes with beads at the bottom. They were rotated at MAGNA Lyser homogenizer at $3000 \mathrm{rpm}$ for 30 seconds. The removed tubes from the homog-

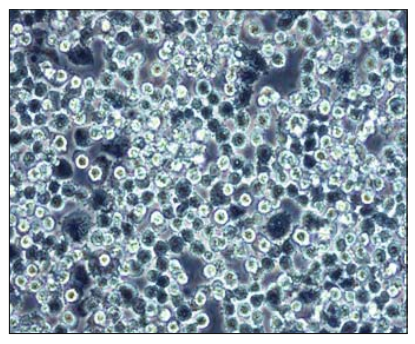

Control

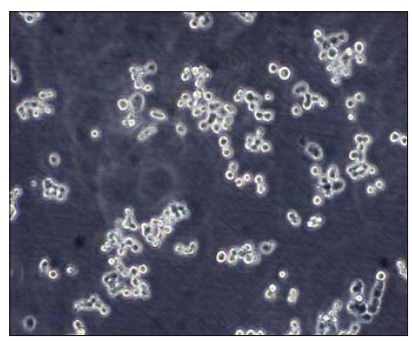

17-AAG application
Fig. 1. Cells that are semi-confluent and confluent in Colo 205 colon cancer cell lines. enizer were taken to the cooling block and allowed to stay at room temperature for $5 \mathrm{~min}$. Then 200 microliters of chloroform were added to the tubes, incubated for $5 \mathrm{~min}$ at $4{ }^{\circ} \mathrm{C}$ for 20 minutes and centrifuged at $12.000 \mathrm{rpm}$. This process results in DNA, RNA and protein was obtained as 3 phases. 1st phase (aqueous phase): includes RNA, colorless. 2nd Phase: contains DNA, is white. Phases 3 (organic phase); includes proteins, is red. For RNA isolation, it was put into 500 microliter colorless phase 1 tubes. 500 microliters of isopropanol were added on. They were incubated for $10 \mathrm{~min}$ at room temperature. They were centrifuged $10 \mathrm{~min}$ at $12.000 \mathrm{rpm}$ at $4{ }^{\circ} \mathrm{C} .1 \mathrm{ml} 75 \%$ of ethanol was added on the precipitated form. They were centrifuged at $4{ }^{\circ} \mathrm{C}$ for $5 \mathrm{~min}$ at 12.000 $\mathrm{rpm}$. At the end of centrifugation the supernatant was discarded. $57^{\circ} \mathrm{C}$ ethanol evaporated. Pipetage was done by adding 50-100 microliters of RNA free water to the remaining precipitate. Precipitation was dissolved (18).

\section{cDNA synthesis}

After addition of RNAse-free water, the absorbance of the cells was measured. For each sample, a mixture of total 11.4 microlitre was prepared by 9.4 microliters of RNA $+\mathrm{H}_{2} \mathrm{O}$ and 2 microliters by random hexamer primer. This mixture was taken into smaller tubes and pipetage was performed. Afterwards the tubes were placed in Thermalcycler. It was incubated at $65^{\circ} \mathrm{C}$ for $10 \mathrm{~min}$. Mastermix was prepared in the meantime. For each sample, 4 microliters of the reaction buffer, dNTP 2 microliters, 1 microliter DTT, 1.1 microliters enzyme, 0.5 microliters of RNAse inhibitor was prepared for a total of 8.6 microliters mastermix. Prepared mastermix (8.6 microliters) was added to the samples (11.4 microliters) taken from thermalcycler and the pipetage was performed. Final volume of cDNA samples was completed to $20 \mu$ l. Then, the tubes were placed in a thermal cycler and run according to the schedule below; at $55^{\circ} \mathrm{C}$ and $85^{\circ} \mathrm{C}$ for $30 \mathrm{~min} 5 \mathrm{~min}$ (18).

\section{Real time PCR process}

cDNA sample was prepared so that the final volume of the reaction mixture was $10 \mu 1$. For each sample, $3.5 \mathrm{ml}$ of $\mathrm{dH}_{2} \mathrm{O}, 0.5 \mathrm{ml}$ of the probe primer mix, $5 \mathrm{ml}$ of $9 \mathrm{ml}$ of enzyme mixture were to be obtained. To this mixture, $1 \mu \mathrm{cDNA}$ sample was added and pipetage was performed. The reaction mixture was distributed to in each well of 96-well plate in amount of $10 \mu \mathrm{l} \mathrm{PCR}$ and was also continued to read. After one hour reading activity took place in PCR (18).

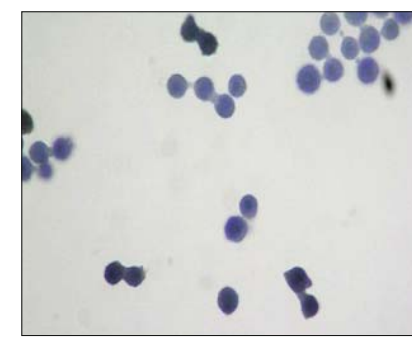

Without 17-AAG

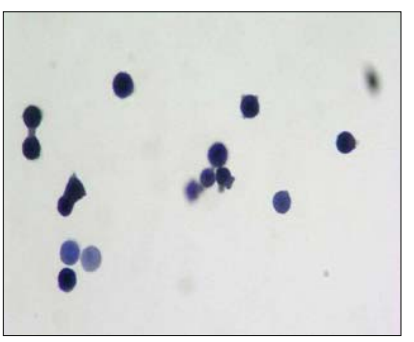

With 17-AAG
Fig. 2. Images of the cells according to the TUNEL method. 
Tab. 1. The values of expressions of apoptotic factors on Colo 205 cell lines after treatment with 17-AAG by RT-PCR analysis.

\begin{tabular}{|c|c|c|c|c|}
\hline & CytochromE & $\mathrm{Bcl}-2$ & Apaf-1 & Caspase 9 \\
\hline Control & $0.00255000 \pm 0.00085000$ & $0.00020100 \pm 0.00015000$ & $0.00024300 \pm 0.00065000$ & $0.00053200 \pm 0.00025000$ \\
\hline $17 \mathrm{AAG}$ & $0.00517000^{\mathrm{a}} \pm 0.00155000$ & $0.00018400^{\mathrm{a}} \pm 0.00015000$ & $0.00051600^{\mathrm{a}} \pm 0.00035000$ & $0.00107000^{\mathrm{a}} \pm 0.00045000$ \\
\hline
\end{tabular}

a - when compared relative to control $\mathrm{p}<0.05$

\section{Statistical methods}

SPSS 15.0 statistical program was used to evaluate the data obtained from the experiments. The significance of differences between groups was evaluated by Mann-Whitney U test. The level of significance was accepted as $\mathrm{p}<0.05$ (19).

\section{Results}

The passaged cells of Colo-205 were observed as small and round shape with weak and late adhesion to the tissue culture plastic. They showed spiny protrusions with stick to other cells and they preserved their roundness. They were rarely viewed as bipolar morphology. There was clear death effect of 17-AAG which killed most of the cells (Fig. 1).

There was apoptotic cell death after the application of 17-AAG at IC50 dose which was 8.06 uM (Fig. 2). The cells with smaller, chromatin condensation, bleb and protrusions morphology were observed by the toxic effect of 17-AAG. Apoptotic index was changed from $1.2 \pm 0.6$ to $2.5 \pm 0.5$ under the effect of 17-AAG.

The effect of gene expressions colon cancer cells treated with 17-AAG. Treatment doses are looked with RT-PCR analysis (Tab. 1). After the application of cytochrome c, apaf-1, caspase 9 protein expression values significantly $(\mathrm{p}<0.05)$ increased while the value of bcl-2 expression significant $(\mathrm{p}<0.05)$ decreased.

\section{Discussion}

Colon cancer is one of the most common malignancies which was the third reason for the annual worldwide cancer related deaths with 1 million new cases and more than 600.000 annual death estimates (5). Apoptosis is a programmed cell death which is regulated by many proteins (20). Apoptosis is a target for the cancer treatment (4). It has been shown that apoptosis is associated with the elimination of the potential cancer cells and tumor growth (21). In this study, we showed the induction of apoptosis in the colon cancer cell line with the alterations of apoptosis related genes. Similarly, previous study has shown increase of mitochondria related and death receptor-mediated apoptosis in Colo-205 cells (22).

HSP-90, a heat shock protein, inhibits apoptotic response due to its cellular protective nature. Geldanamycin and its derivatives play an important role in inhibiting of HSP-90. 17-AAG is the first HSP-90 inhibitor which prevents its protective feature and provides the occurrence of apoptosis in cells. This study and previous studies showed that 17AAG has significant apoptotic and cytostatic activity on colon cancer $(12,15)$. 17-AAG binding to HSP-90 with the provision of destruction oncogenic proteins such as Raf-1 and Akt caused cell cycle arrest and apoptosis in differ- ent type of colon cancer cell lines (HCT116, HCT15, HT29) by blocking the signal transmission $(13,14)$.

Bcl-2 plays an significant role in the occurrence of apoptosis. The reduction of the bcl-2 has been reported to inhibit the mitochondrial release of cytochrome $\mathrm{c}$ of bcl-2, caspase activation and the prevention of anti-apoptotic effect (23). In our study, bcl-2 expressions was decreased significantly after 17-AAG treatment. This observation was supported by the previous studies. Similar results have been also shown by the studies of acute myleoid leukemia (24) and breast cancer cell line (25). The application of bcl-2 antagonist with 17-AAG caused anti-tumor activity in the cancer cells resistant to apoptosis due to high levels of bcl-2 (26).

Apoptotic cell death in the cells that were inhibited by HSP90 takes place by the release of cytochrome c to cytosol by mitochondrial way (27). In our study, it was shown that the expression of cytochrome-c was increased statistically significantly after treated with the 17-AAG on the colon cancer cell line. It was similar to previous studies where there was a decrease of bcl-2 expression and an increase of the cytochrome c and caspase 9 expressions $(26,28)$.

It has been reported that apaf- 1 and caspase 9 are required for the cytochrome-c induced apoptosis (29). We found in our study that apaf-1 expression was increased significantly after 17-AAG application in colon cancer cell line and in HL-60 cell line (30).

Caspases are the central components of apoptotic program with an active role (31). In this study, it was determined that caspase 9 increased statistically significantly on colon cancer cell line when treated with 17-AAG. This was similar to apoptotic cell death in bladder cancer cells (31) and lymphoma cells (32) in which 17-AAG-induced cell death increased expression of important elements of apoptosis such as caspase 9 and caspase 3 .

In conclusion, the application of 17-AAG on colon cancer line caused induction of apotosis with the statistically significant expressions of apoptotic proteins such as cytochrome c, apaf-1, caspase 9 and reduction of anti-apoptotic protein bcl-2. Therefore, the application of 17-AAG appears to to contribute to the treatment of colon cancer. By the help of natural product 17-AAG to the colon cancer treatment may help survival of cancer patients.

\section{References}

1. Akyol S. Over Kanserinde Sicak Şok Proteinleri (HSP) ve Progesteron Reseptörleri (PR). Bakirköy Tip Dergisi 2009; 5 (3): 83-91.

2. Douglas RG, Reid PB, Thomas GC. Apoptosis and cancer. Principl Pract Oncol 1994; 1: 1-13.

3. Durhan E. Kolon kanser tanili olgularda PCR RFLP metodu ile p53 gen mutasyonlarinin saptanmasi. (Yüksek Lisans Tezi) Afyon Kocatepe Üniversitesi, 2006. 
4. Wei Q, Kazimierz S, Kadiiska M. Mechanism of arsenic-induced cross tolerance to nickel cytotoxicity, genotoxicit and apoptosis in rat liver epithelial cells. Toxicol Sci 2001; 63: 189-195.

5. He X, Dong Y, Wah Wu C, Zhao Z, Simon SM, Chan FKL, Sung J, Yu J. MicroRNA-218 Inhibits Cell Cycle Progression and Promotes Apoptosis in Colon Cancer by Downregulating BMI1 Polycomb Ring Finger Oncogene. Mol Med 2012; 18: 1491-1498.

6. Akpinar G. Kolon kanserinde apoliprotein e (apo e) gen poliferizminin araştirilmasi. Kocaeli Üniversitesi, 2006.

7. Duranyildiz D, Oğuz H, Çamlica H, Yasasever V, Topuz E. Malign Melanomali Hastalarda Serum BCL-2 düzeyleri. Türk Onkoloji Dergisi 2004; 19: 131-133.

8. Goldstein JC, Waterhouse NJ, Juin P, Evan GI, Gren DR. The coordinate release of cytochrome $\mathrm{c}$ during apoptosis is rapid, complete and kinetically invariant. Nat Cell Biol 2000; 2 (3): 156-162.

9. Sreedhar AS, Csermely P. Heat shock proteins in the regulation of apoptosis: new strategies in tumor therapy A comprehensive review. Pharmacol Ther 2004; 101: 227-257.

10. Parcellier A, Gurbuxani S, Schmitt E, Solary E, Garrido C. Heat shock proteins, cellular chaperones that modulate mitochondrial cell death pathways. Biochem Biophys Res Commun2003; 304: 505-512.

11. Piner P. Lambda-Cyhalothrinin Oreochromis niloticus'da karaciğerde piperonil bütoksit modülarörlüğünde oksidatif stres potansiyelinin belirlenmesi, stres proteinleri ve apoptozis üzerine etkileri. Çukurova Üniversitesi, 2009.

12. Kelland LR, Sharp SY, Rogers PM, Myers TG, Workman P. DTDiaphorase Expression and Tumor Cell Sensitivity to 17-Allylamino,17demethoxygeldanamycin, an Inhibitor of Heat Shock Protein 90. J Natl Cancer Inst 1999; 91 (22): 1940-1949.

13. Clarke PA, Hostein I, Banerji U, Di Stefano F, Maloney A, Walton M, Judson I, Workman P. Gene expression proßling of human colon cancer cells following inhibition of signal transduction by 17 -allylamino17-demethoxygeldanamycin, an inhibitor of the hsp90 molecular chaperone. Oncogene 2000; 19: 4125 - 4133.

14. Hostein I, Robertson D, DiStefano F, Workman P, Clarke PA. Inhibition of Signal Transduction by the Hsp90 Inhibitor 17-Allylamino17-demethoxygeldanamycin Results in Cytostasis and Apoptosis. Cancer Res 2001; 61: 4003-4009.

15. Moser C, Lang SA, Stoeltzing O. Heat-shock Protein 90 (Hsp90) as a Molecular Target for Therapy of Gastrointestinal Cancer. Anticancer Res 2009; 29: 2031-2042.

16. Vural K, Tuğlu MI. Neurotoxic effect of statins on mouse neuroblastoma NB2a cell line. Eur Rev Med Pharmacol 2011; 15: 985-991.

17. Vatansever HS, Sorkun K, Deliloğlu-Gurhan SI, Ozdal-Kurt F, Turkoz E, Gencay $\mathbf{O}$, Salih B. Propolis from Turkey induces apoptosis through activating caspases in human breast carcinoma cell lines. Acta Histochem 2010; 112: 546-556.

18. Kosova F, Kurt FO, Olmez E, Tuğlu I, Ari Z. Effects of caffeic acid phenethyl ester on matrix molecules and angiogenetic and anti-angiogenetic factors in gastric cancer cells cultured on different substrates. Biotech Histochem 2016; 91 (1): 38-47.
19. Duzagac F, Inan S, Ela Simsek F, Acikgoz E, Guven U, Khan SA, Rouhrazi H,Oltulu F, Aktug H, Erol A, Oktem G. JAK/STAT pathway interacts with intercellularcell adhesion molecule (ICAM) and vascular cell adhesion molecule (VCAM) while prostate cancer stem cells form tumor spheroids. J Buon 2015; 20 (5): 1250-1257.

20. Özkaya AB. HCT-116 Kolon Kanser Hücre Hattinda Yeşil Çay Etken Maddesi Olan (-)-Epigallokatekin-3-gallatin Apoptoz Üzerine Etkisinin İncelenmesi. (Yüksek Lisans Tezi) Dokuz Eylül Üniversitesi; 2008.

21. Kerr JFR, Wyllie AH, Currie AR. Apoptosis: A Basic Biological Phenomenon With Wideranging Implications In Tissue Kinetics. Br J Cancer 1972; 26: 239-257.

22. Watanapokasin R, Jarinthanan F, Nakamura Y, Sawasjirakij N, Jaratrungtawee A, Suksamrarn S. Effects of $\alpha$-mangostin on apoptosis induction of human colon cancer. World J Gastroenterol 2011; 17 (16): 2086-2095.

23. Cohen-Saidon C, Carmi I, Keren A, Razin E. Antiapoptotic function of Bcl-2 in mast cells is dependent on its association with heat shock protein 90. Blood 2006; 107: 1413-1420.

24. Flandrin P, Guyotat D, Duval A, Cornillon J, Tavernier E, Nadal N, Campos L. Significance of heat-shock protein (HSP) 90 expression in acute myeloid leukemia cells. Cell Stress Chaperones 2008; 13: 357-364.

25. Ferrario A, Rucker N, Wong S, Luna M, Gome C. Survivin, a Member of the Inhibitor of Apoptosis Family, Is Induced by Photodynamic Therapy and Is a Target for Improving Treatment Response. Cancer Res 2007; 67 (10): 4989-4995.

26. Nimmanapalli R, O'Bryan E, Kuhn D, Yamaguchi H, Wang H, Bhalla K. Regulation of 17-AAG-induced apoptosis: role of Bcl-2, Bcl-Xl and Bax downstream of 17-AAG-mediated down-regulation fAkt, Raf-1, and Src kinases. Blood 2003; 102: 269-275.

27. Margineantu DH, Emerson CB, Diaz D, Hockenbery DM. Hsp90 Inhibition Decreases Mitochondrial Protein Turnover. PLoS One 2007; 2 (10): e1066.

28. Hsu S, Lu J, Kuo C, Yang J, Lin M, Chen G, Su C, Lu H, Chung J. Crude Extracts of Solanum lyratum Induced Cytotoxicity and Apoptosis in a Human Colon Adenocarcinoma Cell Line (Colo 205). Anticancer Res 2008; 28: 1045-1054.

29. Wright KM, Smith MI, Farrag L, Deshmukh M. Chromatin modification of Apaf-1 restricts the apoptotic pathway in mature neurons. J Cell Biol 2007; 179: 825-832.

30. Dias S, Shmelkov SV, Lam G, Rafii S. VEGF165 promotes survival of leukemic cells by Hsp90-mediated induction of Bcl-2 expression and apoptosis inhibition. Blood 2002; 99 (7): 2532-2540.

31. Karkoulis PK, Stravopodis DJ, Margaritis LH, Voutsinas GE. 17-Allylamino-17-demethoxygeldanamycin induces downregulation of critical Hsp90 protein clients and results in cell cycle arrest and apoptosis of human urinary bladder cancer cells. BMC Cancer 2010; 10: 481-495.

32. Georgakis GV, Li Y, Younes A. The heat shock protein 90 inhibitor 17-AAG induces cell cycle arrest and apoptosis in mantle cell lymphoma cell lines by depleting cyclin D1, Akt, Bid and activating caspase 9. Br J Haematol 2006; 135 (1): 68-71. 